\title{
WAR, CIVIL LIBERTIES AND THE SUPREME COURT 1941 to 1946 *
}

\author{
OSMOND K FRAENKEL广ั
}

WAR is a notorious interferer with liberty. This is so inevitably since military necessities do not brook the delays which characterize the deliberations of civil life. Everyone knows the tendency to impose uniformity of thought and behavior during war, and that the executive arm of the government tends to encroach upon the liberty of the individual in all the areas protected by the Bill of Rights-freedom of expression, freedom of motion and freedom from arbitrary punishment.

In considering the extent to which such infringement is constitutionally permissible, we must apply certain general concepts to the relations between the various constitutional provisions. The Constitution both authorizes war and protects freedom. Obviously no one of its provisions has greater force than any other. The Bill of Rights and those provisions of the original Constitution which affect freedom do not lose their efficacy because Congress, in the exercise of its constitutional power, has declared war. That this is so with regard to the habeas corpus guarantee is apparent on its face, since in express terms that guarantee contemplates a state of war. The same is true also with regard to trial by jury, freedom of expression and guarantee of due process.

While it is true that the Bill of Rights persists even in wartime it cannot be denied that war can affect the meaning of some of its provisions. For instance, the rights of freedom of speech and of the press are not absolute. Their meaning, in peace as well as in war, depends upon the circumstances under which they are exercised. Freedom of expression may conflict with other essential functioning of a democratic community. Thus the question has arisen whether an employer's freedom of speech may be restricted by an administrative agency concerned with preventing industrial strife. ${ }^{1}$ Again the right of a municipality to tax the sale of leaflets may collide with freedom of religion

\footnotetext{
*Since this article deals only with personal rights it has not discussed Yaluus v. United States, 321 U. S. 414 (1914), opinion by the Chief Justice, discenting opinions by Mr. Justice Roberts and Mr. Justice Rutledge; the latter dissent concurred in by MIr. Justice Murphy. There the majority held that a defendant in a criminal prosecution under the Emergency Price Control Act could not challenge the correctness of the O.P.A. order he vas charged with violating. Congress had established an exclusive method for maling such a challenge which was valid and must be followed. The dissenters expressed the view that the method provided in the law for challenge of orders lacked due process. Nor do vie consider at all cases such as Bowles v. Willingham, 321 U. S. 503 (1944); Steuart \& Bro. v. Bowles, 322 U.S. 398 (1944).

$\dagger$ Member of the New York Bar.
}

1. NLRB v. Virginia Electric \& Power Co., 314 U.S. 469 (1941). 
or the press. ${ }^{2}$ The line between such criticism of the courts as is protected by the Constitution and such as may be punished as contempt of court remains clearly to be drawn. ${ }^{3}$

It is not strange, therefore, that war should present special problems in the particular field of freedom of expression. Freedom of the press has a different meaning in war time from that which it has in time of peace. No one would challenge the government's right to forbid publication of statements which could convey valuable information to the enemy. And so, censorship of news of military importance becomes inevitable in wartime, when it would not be tolerated in time of peace.

By no means does it follow, however, that in wartime it becomes proper to suppress all expression of opinion hostile to the war or its purposes. Naturally, the majority, when war appears imminent or has actually occurred, desires to impose unification of opinion on the country. Attempts are then made to silence dissenters, sometimes by executive action suppressing meetings or newspapers, sometimes by banning material from the mails, sometimes by criminal prosecution. The right of the government to pursue these courses has been both attacked and defended by men whose devotion to the ideals of our country remains unquestioned.

Thus Jefferson opposed, as unconstitutional, the restrictive Alien and Sedition Act sponsored by his predecessor, Adams. ${ }^{4}$ On the other hand, Lincoln sought to justify the detention of numerous persons without trial by the argument that, while he was engaged in saving the main body of the Constitution, a temporary deviation from its provisions would produce no permanent harm any more than would a patient of necessity acquire the habit of using emetics simply because these had been prescribed for him during a serious illness. ${ }^{b}$

It is, however, more difficult to justify interference with personal liberty during wartime than it is to justify some restriction on freedom of expression. Certainly this is true in connection with prosecutions for crime. The various provisions of the Bill of Rights on this subject are very explicit indeed and can hardly be interpreted one way in time of peace and another way in wartime. The safeguards of indictment and jury trial, the rights to counsel and to confrontation of witnesses apply to ordinary crimes at all times, and no sound basis exists for disregard-

2. Jones v. Opelika, 316 U. S. 584 (1942), vacated 319 U. S. 103 (1943); Murdock v. Pennsylvania, 319 U.S. 105 (1943); Martin v. City of Struthers, 319 U. S. 141 (1943); Follett v. Town of McCormick, 321 U. S. 573 (1944); Marsh v. Alabama, 66 Sup. Ct. 276 (U. S. 1946).

3. Bridges v. California, 314 U. S. 252 (1941); see also Pennekamp v. Florida, 22 So. (2d) 875 (Fla. 1945) cert. granted, 66 Sup. Ct. 146 (U.S. 1945).

4. Letter to Stephens T. Mason, Oct. 11, 1798, 7 The Writings of Thomas Jefrersox (Ford's ed. 1896) 282-3. See also Virginia Resolutions sponsored by Jefferson.

5. Letter to Honorable Erastus Corning and others, June 12, 1863, 2 ABRArass LiNCOLN-COMPLETE WORKs (Nicolay and Hay ed. 1894) 345. 
ing them except where the status of the individual brings him under military law. And even then, as we shall see, problems arise as to the application here of the due process clause.

Additional aspects of personal liberty come into question when, through the declaration of martial law or even the mere exercise of authority by the military, the freedom of an individual is interfered with without his subjection to criminal prosecution. No express constitutional guarantees exist in this field other than the right to involse the writ of habeas corpus. The controversy which raged during the Civil War as to where the power resided to suspend the writ of habeas corpus has had no recent replica. In the continental United States the writ has not since that time been suspended.

Different criteria must be applied in deciding whether particular executive acts transcend constitutional barriers, depending on the nature of the guarantees affected. If the guarantee is of the procedural character specified in the Fourth, Fifth or Sixth Amendments, no difficult philosophical problem need arise. The main determining factor should then be one of classification only. Is the person involved subject to military law or is he not? There should, therefore, be no question of weighing alleged military necessity in this field. On the other hand, in dealing with the rights specified in the First Amendment or with the liberty of the individual not protected by specific guarantees more complicated questions can be considered. Here there may be a balancing of conflicting interests. Paramount military needs can properly be weighed; and the "clear and present danger" test " applied.

In the last analysis, decisions will be determined by the relative values judges give to the two apparently antagonistic needs of a community at war: the immediate necessity for winning the war and the everlasting requirement that liberty be preserved. To some extent, of course, particular decisions will be affected by the accident of time. In the days before the outcome of a war is clear, courts will be inclined to favor the present need over the future freedom. Once the war is won, ideals of liberty become more persuasive. Throughout all these upheavals the United States Supreme Court remains, of course, the final arbiter between the liberties of the individual and the war power wielded by the executive. In every war it has been called on to exercise this great function.

The war just ended has been no exception. The Supreme Court has, however, followed no such pattern of acquiescence in governmental action as marred the Court's record in the cases which arose out of the First World War. Then the Court upheld all the convictions brought before it under the Espionage Act," allowed the Postmaster General

6. Schenck v. United States, 249 U.S. 47 (1919).

7. Commencing with Schenck v. United States, 249 U. S. 47 (1919) through Picrce v. United States, 252 U. S. 239 (1920) (in this and some other cases Mr. Justice Holmes and Mr. Justice Brandeis dissented). 
great powers of censorship, ${ }^{8}$ and refused to interfere with state wartime restrictions on liberty. ${ }^{9}$

This time the Supreme Court has shown greater wisdom and keener discrimination. Some credit for the result is due the Roosevelt Administrations, whose officials allowed greater latitude to anti-war views than had been permitted under President Wilson. The great body of civil liberties law developed in the nineteen thirties under the leadership of Chief Justice Hughe's ${ }^{10}$ had also had its effect. But before that influence had gathered momentum the Court decided a group of cases related to our topic, the impact of which is still felt.

In 1926 Rosika Schwimmer, who had been one of the sponsors of the Peace Ship of 1916, attempted to become an American citizen. As required by governmental regulations but not by any Act of Congress, she was asked to answer a question regarding her willingness to bear arms. Because she declared that her views as a pacifist forbade an affirmative answer the Supreme Court denied her application on the ground that she was not attached to the principles of the Constitution. ${ }^{11}$ Justices Holmes, Brandeis and Sanford dissented. And when the same question came up several years later in the cases of Professor Macintosh ${ }^{12}$ and Marie Bland ${ }^{13}$ the Court held to its earlier view. This time Chief Justice Hughes, who had just rejoined the Court after his unsuccessful bid for the Presidency, wrote the dissenting opinion, concurred in by Justices Holmes, Brandeis and Stone, the latter having changed his views. However, none of the dissenters questioned the power of Congress to bar pacifists from citizenship; they merely believed that Congress had not intended doing so. Although for many years the Court refused to depart from the rule laid down by these

8. United States ex rel. Milwaukee Social Democratic Publishing Co. v. Burleson, 255 U. S. 407 (1921) (Mr. Justice Holmes and Mr. Justice Brandeis dissented). In contrast to the views there expressed see Hannegan v. Esquire, 66 Sup. Ct. 429 (U. S. 1946). This case had nothing to do with war, however.

9. Gilbert v. Minnesota, 254 U. S. 325 (1920). Mr. Justice Holmes concurred in the result; Mr. Justice Brandeis dissented (as also Mr. Chief Justice White, but on a narrow ground). Cf. Gitlow v. New York, 268 U. S. 652 (1925) (Mr. Justice Holmes and Mr. Justice Brandeis dissenting); Whitney v. California, 274 U. S. 357 (1927) (Mr. Justice Holmes and Mr. Justice Brandeis concurring specially).

10. See Fraenkel, One Hundred and Fifty Years of the Bill of Rights (1939) 23 MrNs. L. ReV. 719; FraENKel, OUR CIVIL LIBERTIES (1944).

11. United States v. Schwimmer, 279 U. S. 644 (1929) (opinion by Mr. Justice Butler; dissenting opinion by Mr. Justice Holmes, concurred in by Mr. Justice Brandeis; Mr. Justice Sanford dissented on the basis of the Circuit Court's opinion).

12. United States v. Macintosh, 283 U. S. 605 (1931) (opinion by Mr. Justice Sutherland; dissenting opinion by Mr. Chief Justice Hughes, concurred in by Mr. Justice Holmes, Mr. Justice Brandeis and Mr. Justice Stone).

13. United States v. Bland, 283 U. S. 636 (1931) (opinion by Mr. Justice Sutherland; dissenting opinion by Mr. Chief Justice Hughes, concurred in by Mr. Justice Holmes, Mr. Justice Brandeis and Mr. Justice Stone). 
cases and until recently even expanded it, at last on April 22, 1946, it reached a different conclusion and expressly overruled the earlier cases in Girouard \%. United States. ${ }^{14}$ The late Chief Justice announced a dissenting opinion just before he was stricken and died. In this he was joined by Justices Reed and Frankfurter.

Another, much later, group of cases also touches our subject. The witnesses of Jehovah interpret the Bible literally and will honor no secular symbol, not even the flag. In consequence their children have in many communities been expelled from schools because of their refusal to salute the flag. At first the Supreme Court refused even to hear argument in these cases, brought from various state courts. ${ }^{15}$ Then, in 1940, in Minersuille School District v. Gobilis, ${ }^{15}$ it upheld the challenged state action. Justice Frankfurter, for the majority, said that since the state had the right to promote patriotism, the courts could not scrutinize the means employed. He stressed the importance of national cohesion: "National unity is the basis of national security." Only Justice Stone dissented. Three years later, however, the Court reversed itself. ${ }^{17}$ Some of the other members had already expressed regret at their earlier decision ; ${ }^{18}$ only Justices Roberts and Reed now stood by Justice Frankfurter. The new opinion, by Justice Jackson, eloquently proclaimed that compulsory unification of opinion was contrary to the essential character of our government.

By the time this decision came down we were at war and the first of the strictly war cases had been decided. That was Ex parte Quirin, ${ }^{10}$ the case of the Nazi saboteurs landed on our shores by submarine. They had challenged the right of the government to try them by military commission, arguing that they were entitled to the guarantees of the Bill of Rights, to be indicted by a grand jury and tried before a petit jury. The government questioned their right to appeal to the courts at all. In an opinion by Chief Justice Stone the Supreme Court unanimously upheld their right to judicial scrutiny of their claims, but rejected them all. The Court accepted the government's contention that the men were subject to military trial because they had entered the country surreptitiously. It ruled that none of the specific guarantees of the Bill of Rights on which they had relied applied to military trials.

14. Girouard v. United States, 66 Sup. Ct. 826 (U. S. 1946).

15. Gabrielli v. Knickerbocker, 12 Cal. (2d) 85, 82 P. (2d) 391 (1938), ccrl. denicd 305 U. S. 621 (1939); Leoles v. Landers, 184 Ga. 580, 192 S. E. 218 (1937), cppral dismissed 302 U. S. 656 (1937); Hering v. State Board of Education, 118 N. J. L. 566, 194 Atl. 177 (1937), appeal dismissed 303 U.S. 624 (1938).

16. 310 U.S. $586(1940)$.

17. West Virginia State Board v. Barnette, 319 U.S. 624 (1943).

18. Mr. Justice Black, Mr. Justice Murphy and Mr. Justice Douglas in Jones v. Opelika, 316 U. S. 584, 623 (1942).

19. 317 U. S. 1 (1942) (opinion by the late Chief Justice; Mr. Justice Murphy tools no part). 
Since then the Court has dealt with a great variety of wartime subjects. Yet a review of the current wartime decisions leaves one with mixed emotions. The reason is readily seen after a brief comparison of the cases in which the Court upheld individual liberty with those in which it supported the government. Even an extended discussion of the more important of these cases leaves doubt of the basic position the Court took. Only Justice Murphy has been consistent throughout; the late Chief Justice and Justice Frankfurter were often in agreement at the opposite pole.

Unanimity in these decisions has been rare, but not entirely absent. All the Justices agreed that a Mississippi statute improperly infringed free speech because it made utterances "calculated to encourage dis. loyalty" a criminal offense; ${ }^{20}$ that cancellation of citizenship for mere expression of pro-Nazi opinion was improper; ${ }^{21}$ and that loyal citizens of Japanese ancestry could not be detained against their will in the relocation centers to which they had been evacuated after Pearl Harbor. ${ }^{22}$ The majority of the Court refused to be stampeded by any red bogey, in either denaturalization or deportation proceedings. ${ }^{23}$ Three convictions were set aside by five to four decisions for insufficiency of proof; in one case, ${ }^{24}$ because circulation of anti-war documents did not indicate an intent to cause insubordination in the armed forces; in a treason case, ${ }^{25}$ for lack of the two witnesses required by the Constitution; in the third, ${ }^{26}$ under the Draft Act, because no intent to evade the draft had been established, merely by the showing that officers of the German-American Bund had advised members not to register

20. Taylor v. Mississippi, 319 U. S. 583 (1943) (opinion by Mr. Justice Roberts).

21. Baumgartner v. United States, 322 U. S. 665 (1944) (opinion by Mr. Justice Frankfurter, concurring opinion by Mr. Justice Murphy, in which Mr. Justice Black, Mr. Justice Douglas and Mr. Justice Rutledge joined).

22. Ex parte Mitsuye Endo, 323 U. S. 283 (1944) (opinion by Mr. Justice Douglas, concurring opinions by Mr. Justice Roberts and Mr. Justice Murphy).

23. Schneiderman v. United States, 320 U. S. 118 (1943) (opinion by Mr. Justice Murphy, concurring opinions by Mr. Justice Douglas and Mr. Justice Rutledge; dissenting opinion by the Chief Justice, in which Mr. Justice Roberts and Mr. Justice Frankfurter joined. Mr. Justice Jackson took no part). Bridges v. Wixon, 326 U. S. 135 (1945) (opinion by Mr. Justice Douglas, concurring opinion by Mr. Justice Murphy; dissenting opinion by Mr. Justice Stone, in which Mr. Justice Roberts and Mr. Justice Frankfurter joined. Mr. Justice Jackson took no part).

24. Hartzel v. United States, 322 U. S. 680 (1944) (opinion by Mr. Justice Murphy, concurring opinion by Mr. Justice Roberts; dissenting opinion by Mr. Justice Reed, in which Messrs. Justices Douglas, Frankfurter and Jackson joined). The narrow scope of this case is indicated by the denial of certiorari in Gordon v. United States, 138 F. (2d) 174 (C. C. A. 7th, 1943), cert. denied 320 U. S. 728 (1943). The only difference is that Gordon urged Negroes not to fight for the United States, while Hartzel made no specific reference to the armed forces.

25. Cramer v. United States, 325 U. S. 1 (1945) (opinion by Mr. Justice Jackson; dissenting opinion by Mr. Justice Douglas, in which the Chief Justice and Messrs. Justices Black and Reed joined).

26. Keegan v. United States, 325 U. S. 478 (1945) (opinion by Mr. Justice Roberts, 
until the application of the law to them had been determined. Finally, over dissents by Justices Burton and Frankfurter, the Court has ruled that the army had no right to try civilians in Hawaii in 1942 and 1944.27

On the other hand, in 1943 the Court refused to review the conviction of a group of Minneapolis Trotzkyites charged with violation of the Smith peacetime Sedition Act, because, before Pearl Harbor, they had circulated anti-war statements and the usual Marxist "revolutionary" literature. ${ }^{28}$ In addition, the Court unanimously upheld the curfew orders issued as a preliminary to the West Coast evacuation of Japanese-Americans ${ }^{29}$ and, over the dissents of Justices Murphy and Jackson, upheld the evacuation itself. ${ }^{\circ} \mathrm{By}$ a five to four vote Illinois was allowed to exclude a pacifist from admission to the bar. ${ }^{32}$ The Court refused to interfere with the military tribunals which sentenced Generals Yamashita and Homma to death for atrocities committed by their troops. ${ }^{32}$ Finally, the Court failed, until it was too late to be of service to the majority of those involved, to find any way by which selective service classifications could be reviewed before actual induction into the armed forces.

\section{II}

The lineup of the Court in the war cases has varied considerably. Justices Reed and Douglas dissented in all three of the five to four decisions in which criminal convictions were reversed, joined twice by

concurring opinions by Messrs. Justices Black and Rutledge; dissenting opinion by Mr. Justice Stone, joined by Messrs. Justices Douglas, Reed and Jaclsson).

27. Duncan v. Kahanamoku, 66 Sup. Ct. 606 (U. S. 1946) (opinion by Mr. Justice Black, concurring opinions by Messrs. Justices Stone and Murphy; dissenting opinion by Mr. Justice Burton, joined by Mr. Justice Franlfurter. Mr. Justice Jaclison tools no part).

28. Dunne v. United States, 138 F. (2d) 137 (C. C. A. Sth, 1943), cert. deried 320 U.S. 790 (1943), rehearing denied, 320 U. S. \$14, 815 (1944). The refusal to grant certionari is particularly surprising because the lower courts had held the "clear and precent danger" test inapplicable. Cf. Bridges v. California, 314 U. S. 252 (1941) where this test had bren declared to be "the minimum protection to which the individual was entitled."

29. Hirabayashi v. United States, 320 U. S. 81 (1943) (opinion by the Chief Justice, concurring opinions by Messrs. Justices Douglas, Miurphy and Rutledge). This cace also involved the evacuation issue, but decision on this was avoided then beeause the sentences on both counts ran concurrently, and approval of the count based on the violation of the curfew order sufficed to sustain the conviction.

30. Korematsu v. United States, 323 U. S. 214 (1944) (opinion by Mr. Justice Blacl;, concurring ppinion by Mr. Justice Franlfurter; dissenting opinions by MLessrs. Justices Roberts, Murphy and Jackson).

31. In re Summers, 325 U. S. 561 (1945) (opinion by Mr. Justice Reed; dissenting opinion by Mr. Justice Black in which Messrs. Justices Douglas, Murphy and Rutledge joined).

32. Application of Yamashita, 66 Sup. Ct. 340 (U. S. 1946) (opinion by the late Chicf Justice). Application of Homma, 66 Sup. Ct. 515 (U. S. 1946) per cariam memorandum, (Dissenting opinions in each case by Messrs. Justices Murphy and Rutledge. Mr. Justice Tackson took no part in either of these cases). 
the Chief Justice and Justice Jackson and once (although in different cases) by Justices Frankfurter and Black. The late Chief Justice and Justices Roberts and Frankfurter composed the minority in both the cases which involved Communists. In the Hawaiian martial law cases, Justices Burton and Frankfurter dissented.

On the other side of the judicial ledger, Justices Douglas, Murphy and Rutledge refused to agree with all the implications of the curfew decision, although they approved the result reached; and in the evacuation case Justices Roberts, Murphy and Jackson dissented. In the pacifist lawyer's case the dissenters were Justices Black, Douglas, Murphy and Rutledge and in the draft conspiracy case, Justices Frankfurter, Roberts, Murphy and Rutledge. Only Justices Murphy and Rutledge disagreed with the majority in the cases involving the Japanese generals.

Thus in all the cases in which the Court decided against the government, Justices Black, Murphy and Rutledge were the bulwark of the majority-except in the treason case, where Justice Black dissented. But Justice Murphy alone consistently dissented when the majority upheld the government. Justice Jackson took no part in several of these cases, in some instances on account of his former position as Attorney General, and in the latest ones due to his absence as prosecutor in Nüremburg. Except in three of these numerous cases, wherever there was any difference of opinion among the justices, the late Chief Justice was on the "wrong" side.

It should be noted, moreover, that in few of the cases which upset governmental action did the Court lay down any basic constitutional principles. Its failure to do so led, in several of the instances, to special concurring opinions: In the Bund Denaturalization case, ${ }^{33}$ the majority confined itself to discussion of the facts. Justice Murphy, ${ }^{34}$ however, speaking also for Justices Black, Douglas and Rutledge, stressed the right of the naturalized citizen, as well as the native born, to the full exercise of freedom of speech. In the Bridges case, ${ }^{35}$ in which the other justices ruled only that the hearing had been unfair, Justice Murphy ${ }^{30}$ filed an eloquent protest against the failure of the majority to deal with the basic constitutional issues presented. He said: ${ }^{37}$

"Deportation, with all its grave consequences, should not be sanctioned on such weak and unconvincing proof of a real and imminent threat to our national security. Congress has ample power to protect the United States from internal revolution and anarchy without abandoning the ideals of freedom and tolerance.

\footnotetext{
33. Baumgartner v. United States, 322 U. S. 665 (1941).

34. Id. at 678.

35. Bridges v. Wixon, 326 U.S. 135 (1945).

36. Id. at 157 .

37. Id. at $165-6$.
} 
We as a nation lose part of our greatness whenever we deport or punish those who merely exercise their freedoms in an unpopular though innocuous manner. The strength of this nation is wealsened more by those who suppress the freedom of others than by those who are allowed freely to think and act as their consciences dictate.

"Our concern in this case does not halt with the fate of Harry Bridges, an alien whose constitutional rights have been grossly violated. The significance of this case is far reaching. The liberties of the $3,400,000$ other aliens in this nation are also at stake. Many of these aliens, like many of our forebears, were driven from their original homelands by bigoted authorities who denied the existence of freedom and tolerance. It would be a dismal prospect for them to discover that their freedom in the United States is dependent upon their conformity to the popular notions of the moment. But they need not make that discovery. The Bill of Rights belongs to them as well as to all citizens. It protects them as long as they reside within the boundaries of our land. It protects them in the evercise of the great individual rights necessary to a sound political and economic democracy. Neither injunction, fine, imprisonment, nor deportation can be utilized to restrict or prevent the exercise of intellectual freedom. Only by zealously guarding the rights of the most humble, the most unorthodox and the most despised among us can freedom flourish and endure in our land."

In Ex parte Mitsuye Endo ${ }^{3 s}$ the majority decided only that Congress had not authorized the challenged detention in a relocation center for Japanese-Americans evacuated from the W'est Coast. Justices Murphy ${ }^{39}$ and Roberts ${ }^{40}$ alone discussed the constitutional issues left unmentioned by the majority. Here Justice Murphy described what had been done as an "unconstitutional resort to racism inherent in the entire evacuation program." "il

In the Hawaiian martial law case, Duncan v. Kahanamoku, the majority dealt primarily with the meaning of the Organic Act of Hawaii. They concluded that Congress, in authorizing the establishment of martial law, had neither intended to make any special rules in this field with regard to Hawaii, nor contemplated trials of civilians by military courts. Mr. Justice Black noted that the case did not involve a situation of military rule over an area from which civilians had been evacuated nor any specialized effort by the military to enforce only those orders which related to military functions. He stressed the importance of subordinating the military to the civilian authority and said that he believed that Congress "did not wish to exceed the

\footnotetext{
38. 323 U.S. 283 (1911).

39. Id. at 307 .

40. Id. at 308 .

41. Id. at 307 .

42. 66 Sup. Ct. 606 (U.S. 1946).
} 
boundaries between military and civilian power in which our people have always believed, which responsible military and executive officers had heeded, and which had become part of our political philosophy and institutions." 43

The concurrence of the late Chief Justice ${ }^{44}$ was on the narrow ground that the conditions in Hawaii, at least after February 1942, did not involve such a threat to public safety as to justify the substitution of trials by military tribunals for trials in the civil courts.

Justice Murphy ${ }^{45}$ dealt with broader constitutional issues. He believed that the "open court" rule of Ex parte Milligan ${ }^{46}$ was the proper criterion for determining the limits of military trials. He dealt as follows with the argument of military necessity: ${ }^{47}$

"The argument thus advanced is as untenable today as it was when cast in the language of the Plantagenets, the Tudors and the Stuarts. It is a rank appeal to abandon the fate of all our liberties to the reasonableness of the judgment of those who are trained primarily for war. It seeks to justify military usurpation of civilian authority to punish crime without regard to the potency of the Bill of Rights. It deserves repudiation."

Mr. Justice Murphy discussed at length the various specific reasons advanced by the government, some of which had been accepted in the Circuit Court of Appeals. In the course of this discussion, he declared as follows: ${ }^{48}$

"From time immemorial despots have used real or imagined threats to the public welfare as an excuse for needlessly abrogating human rights. That excuse is no less unworthy of our traditions when used in this day of atomic warfare or at a future time when some other type of warfare may be devised. The right to jury trial and the other constitutional rights of an accused individual are too fundamental to be sacrificed merely through a reasonable fear of military assault. There must be some overpowering factor that makes a recognition of those rights incompatible with the public safety before we should consent to their temporary suspension. If those rights may safely be respected in the face of a threatened invasion no valid reason exists for disregarding them. In other words, the civil courts must be utterly incapable of trying criminals or of dispensing justice in their usual manner before the Bill of Rights may be temporarily suspended. 'Martial law [in relation to closing the courts] cannot arise from a threatened invasion. The

43. Id. at 615-6.

44. Id. at 620 .

45. Id. at 616 .

46. 4 Wall. 1 (U.S. 1866).

47. 66 Sup. Ct. 606 , at 618 .

48. Ibid. 
necessity must be actual and present; the invasion real, such as effectively closes the courts and deposes the civil administration.' Ex parte MIIligan, 4 Wall. 1, at page 127."

The dissenters began their opinion with a declaration of adherence to the Bill of Rights. However, they pointed out that, since the Constitution expressly provides for waging war and vests the war power in the executive, the Court should refrain from over-expanding its control into the field allotted to another branch of government. They rejected the criteria relied upon by the majority and believed that the executive power in wartime was supreme in any area which could be described as the "theatre of actual military operations." They cited the declarations made immediately after Pearl Harbor as a recognition by the executive that Hawaii constituted a theatre of war.

The dissenting opinion seems somewhat confused in that it recognizes limits to the extent to which executive discretion can constitutionally delay restoration of civilian control. The opinion indicates no criterion for determining when the judiciary can differ with the military as to the propriety of the delay. Whatever uncertainty may remain, due to difference of opinion among the justices as to the constitutional power of Congress to permit military trials of civilians while the civil courts are open, it is clear the Supreme Court will not permit such trials to be held in the absence of specific congressional authorization. It is to be regretted, nevertheless, that the majority did not seize this opportunity to reaffirm the rule of the Milligan case and did not deal with the question on a fundamental basis.

Only in the treason case, Cramer v. United States, ${ }^{13}$ did the Court discuss fundamental problems. Here, although the chief difference betwreen the judges concerned interpretation of the evidence, the majority discussed at length the meaning of the treason clause in the Constitution. After reviewing the treason prosecutions with which the framers of the Constitution were acquainted, and the proceedings of the Constitutional Convention itself, Mr. Justice Jackson concluded for the majority that the Constitution requires proof by two witnesses that the accused actually had given aid and comfort to the enemy. It was not enough that he merely intended to gire it. Mr. Justice Jackson rejected the suggestion made by the government that the constitutional requirement should be given a loose interpretation lest it be too. difficult to convict. He thus summed the matter up: $: 9$

"The provision was adopted not merely in spite of the difficulties it put in the way of prosecution but because of them. And it was not by whim or by accident, but because one of the most venerated of that venerated group considered that 'prosecutions for treason

49. 325 U.S. 1 (1945).

50. Id. at 48 . 
were generally virulent.' Time has not made the accusation of treachery less poisonous, nor the task of judging one charged with betraying the country, including his triers, less susceptible to the influence of suspicion and rancor. The innovations made by the forefathers in the law of treason were conceived in a faith such as Paine put in the maxim that 'He that would make his own liberty secure must guard even his enemy from oppression; for if he violates this duty he establishes a precedent that will reach himself.' ${ }^{51}$ We still put trust in it."

For the dissenters, ${ }^{52}$ Justice Douglas insisted there was no need to interpret the Constitution so rigorously. He claimed it was undisputed that Cramer knew he was befriending two of the saboteurs who had been landed here by submarine. ${ }^{53}$ The dissenters maintained that the Constitution did not require proof by two witnesses of what Cramer had planned at his meetings with the saboteurs. It was the meetings which constituted the overt acts required to be proved; their treasonable character could be inferred. In any event, the dissenters pointed out, Cramer had told the whole story on the witness stand so that proof that he had actually helped the enemy had come from his own lips. This, they stated, should be treated as though it were a confession in open court, permitted as sufficient proof by the Constitution. That point was completely ignored in the majority opinion.

In any case, this decision, while the first by the Supreme Court dealing with treason, touches only on the technicalities of proof required by the Constitution for the particular offense and has, therefore, no bearing on other war cases.

The constitutional declarations made in the cases in which the Court supported the government were more explicit. The decision in Hirabayashi v. United States, ${ }^{54}$ in which the legality of the West Coast curfew orders was upheld, rested on certain generalities with regard to the war powers and certain particulars with regard to the Japanese-American population. Chief Justice Stone quoted with approval a statement made in an article by former Chief Justice Hughes ${ }^{55}$ to the effect that the power to make war was "the power to wage war successfully" and held that this extended to "every phase of the national defense." He ruled that the courts could not review the exercise of judgment by the executive when approved by Congress. The late Chief Justice concluded that the particular situation called for such exercise, due to the danger to the West Coast following the attack on Pearl Harbor, the large number of persons of Japanese ancestry, many of them Japanese

51. See Brooks, The World of Washington Irving (1944) $73 n$.

52. 325 U. S. 1,48 (1945).

53. These were among the persons involved in Ex parte Quirin, 317 U. S. 1 (1942),

54. 320 U. S. 81 (1943).

55. (1917) 42 A. B. A. REp. 232, 238. 
subjects, and the cohesion of the group. Thus the imposition of a curfew was justified on the score that it had a real relation to protection against sabotage. Chief Justice Stone said also: "In time of war residents having ethnic affiliations with an invading enemy may be a greater source of danger than those of a different ancestry." He was careful to indicate, however, that no more was being decided than that "the curfew order as applied and at the time it was applied, was within the boundaries of the war power." Yet in the later case this reservation was altogether disregarded.

None of the justices dissented in the Hirabayashi case. Justice Murphy ${ }^{56}$ thought it went "to the very brink of constitutional power." He suggested, however, that the displaced persons should not be prevented from going into areas free from danger of attack. Mr. Justice Rutledge ${ }^{57}$ expressed doubt about the broad language of the majority to the effect that it would not review the exercise of discretion by the military, since he thought there might be bounds beyond which the military could go. Justice Douglas, however, ${ }^{13}$ foreshadowed the later decision upholding evacuation and indicated that because the need was great and the time short, "temporary treatment on a group basis" was appropriate. He added that hearings with regard to loyalty should be given later, but that a person affected must first obey the lav and then attack his classification.

With this decision as precedent, Mr. Justice Black dealt very summarily with objections made to the evacuation orders when these came up for consideration in Korematsu v. United States, ${ }^{20}$ in which the Court affirmed the conviction of a Nisei citizen for remaining in an area forbidden him by a military order. He said that exclusion from a war area, like the curfew, had relation to the prevention of espionage and sabotage. Excluding the whole group was justified, due to the lack of time in which to sift the loyal from the disloyal. To the argument that the evacuation order was invalid because part of a comprehensive plan which included detention, Mr. Justice Black answered only that it was not necessarily so, since some who were evacuated were not detained. Moreover, he said the various steps were the subject of separate orders which must be separately considered. He rejected the idea that the case presented an issue of detention in a camp on account of racial prejudice. Mr. Justice Frankfurter ${ }^{\mathrm{C}}{ }^{\mathrm{w}}$ went even further than the others in yielding to the plea of military necessity. For he maintained that a military order appropriate for conducting the war is as valid as an order of the Interstate Commerce Commission within its power to

56. 320 U.S. $\$ 1,109$ (1943).

57. Id. at 114 .

58. Id. at 105 .

59. 323 U.S. 214 (1944).

60. Id. at 224 . 
regulate commerce. The Justice forgets, however, that the due process clause stands guardian of liberty in both cases, and that, therefore, it is no answer merely to point out that a challenged order comes within the scope of one or another department's constitutional field of action.

The dissents ranged over a wide field. Justice Roberts found 01 "a clear violation of constitutional rights." He believed that the offense did not consist of refusal to leave the area involved, but of refusal to be imprisoned in a camp. He pointed out that Korematsu had been forbidden both to leave the area and to stay in his home-the only way he could avoid violating one of these orders was to go to an assembly center. He rejected the suggestion that Korematsu had first to go to the camp and then sue out a writ of habeas corpus.

Mr. Justice Murphy ${ }^{62}$ dissented on broad grounds of public policy. He insisted that there were limits to the doctrine that military discretion could not be reviewed. He could find no "immediate, imminent and impending" public danger sufficient to justify both the racial discrimination and the denial of due process here involved. He pointed out that the military decision rested on a belief in "racial guilt" and on non-military factors concerning which the military had no special competence. He emphasized the fact that it had been possible to give individual hearings to persons of German and Italian ancestry and that the British government had given such hearings to its enemy aliens.

Mr. Justice Jackson ${ }^{63}$ posed the interesting theses that it was no part of the Court's business to pass on the reasonableness of military action and that a civil court should never enforce an order which violates constitutional limitations. While it is refreshing to get away from the mumbo jumbo of "discretion" and "abuse of discretion," the question still remains what orders by military authority do violate the Constitution. And Justice Jackson has not aided us in establishing that criterion. He concluded only that there was a difference between the mild and temporary deprivation of liberty involved in the curfew order and the later evacuation program.

The opinion in Ex parte Summers, ${ }^{64}$ in which a conscientious objector unsuccessfully sought admission to the Illinois bar, brings into sharp focus the different points of view among the members of the Court. As in the flag salute cases, ${ }^{65}$ the line was drawn between religious freedom and secular power. The majority, as in the first (now overruled) flag salute case, relied heavily on the right of the state to decide certain questions for itself. Mr. Justice Reed stressed the finding of

61. Id. at 225 .

62. Id. at 233 .

63. Id. at 245 .

64. 325 U.S. 561 (1945).

65. See notes $16-18$ supra. 
the Illinois Court that Summers was unable, in good faith, to talie the required oath to support the Constitution of the State, because that Constitution contained a clause requiring military service. He recalled that an alien refusing to pledge military service might be denied citizenship ${ }^{66}$ and said that the action of Illinois could not be considered a violation of religious freedom on account of an interpretation of the state oath "when a like interpretation of a similar oath as to the Federal Constitution bars an alien from national citizenship."

The weakness of this reliance on the pacifist citizenship cases is manifest. In the first place, there may be some relationship between willingness to bear arms in support of an adopted country and becoming a citizen. But there is no relationship whatever between bearing arms and practicing law. As Justice Black well said, ${ }^{, 7}$ the State could as easily bar a pacifist from every employment subject to its regulatory power. Moreover, Illinois had never actually drafted anyone since the Civil War and had exempted persons who are exempt by the laws of the United States. Since Summers had been classified as a conscientious objector by the Selective Service authorities, there was no practical likelihood of his ever being called by Illinois. The Illinois authorities had conjured up a ghost in order to keep Summers from practicing his profession.

Furthermore, Mr. Justice Black pointed out that this use of the oath was "an abomination to the founders of this nation," for it was a test oath "designed to impose civil disabilities upon men for their beliefs rather than for unlawful conduct."

The concluding words of this dissent should be perpetually before us: ${ }^{68}$

"I cannot agree that a state can lawfully bar from a semi-public position, a well-qualified man of good character solely because he entertains a religious belief which might prompt him at some time in the future to violate a law which has not yet been and may never be enacted. Under our Constitution men are punished for what they do or fail to do and not for what they think and believe. Freedom to think, to believe, and to worship, has too exalted a . position in our country to be penalized on such an illusory basis."

In Application of Yamashita, ${ }^{\text {c9 }}$ the majority in refusing the Japanese general writs of habeas corpus and prohibition against the American military authorities who had sentenced him to death, dealt very sketchily with the constitutional points which had been raised by

66. See cases cited in notes 11-13 supra, now overruled by Girougrd v. United Stales, 66 Sup. Ct. 826 (U. S. 1946).

67. 325 U.S. 560,575 (1945).

68. Id.at 578 .

69. 66 Sup. Ct. 340 (U.S. 1946). 
defense counsel. However, following the saboteur case, ${ }^{70}$ they did rule that access to the courts was available to anyone tried by a military commission for the purpose of determining whether the commission had jurisdiction. Justices Murphy and Rutledge, ${ }^{71}$ nevertheless, insisted that even a defeated general was entitled to the protection of the due process clause. They maintained that he had been denied due process because his counsel had been given no fair opportunity to prepare his defense and because the military commission was authorized to receive wholly improper evidence. Justice Rutledge said: ${ }^{72}$

"It is not necessary to recapitulate. The difference between the
Court's view of this proceeding and my own comes down in the end
to the view, on the one hand, that there is no law restrictive upon
these proceedings other than whatever rules and regulations may
be prescribed for their government by the executive authority or
the military and, on the other hand, that the provisions of the
Articles of War, of the Geneva Convention and the Fifth Amend-
ment apply.
"I cannot accept the view that anywhere in our system resides
or lurks a power so unrestrained to deal with any human being
through any process of trial. What military agencies or authorities
may do with our enemies in battle or invasion, apart from proceed-
ings in the nature of trial and some semblance of judicial action, is
beside the point. Nor has any human being heretofore been held to
be wholly beyond elementary procedural protection by the Fifth
Amendment. I cannot consent to even implied departure from that
great absolute.
"It was a great patriot who said:
'He that would make his own liberty secure must guard even his
enemy from oppression; for if he violates this duty he establishes
a precedent that will reach himself."

In the Homma case, an application similar to that of Yamashita, ${ }^{73}$,the majority wrote no opinion, but the same two dissenting judges added to the views which they had expressed earlier. They took particular objection to the procedure which permitted the use of confessions obtained by torture. These justices strongly complained that the majority decisions constituted surrender to hysteria and an abandonment of constitutional principles. As Mr. Justice Murphy said: ${ }^{74}$

"Today the lives of Yamashita and Homma, leaders of enemy forces vanquished in the field of battle, are taken without regard

70. See note 19 supra.

71. $66 \mathrm{Sup}$. Ct. at 353,359 . They contended also that the charge did not state a recognized violation of the laws of war and that the Geneva Convention of 1929 had not been observed.

72. Id. at 378 .

73. Application of Homma, 66 Sup. Ct. 515 (U. S: 1946).

74. Id. at 516. 
to due process of law. There will be few to protest. But tomorrow the precedent here established can be turned against others. A procession of judicial lynchings without due process of law may now follow. No one can foresee the end of this failure of objective thinking and of adherence to our high hopes of a new world. The time for effective vigilance and protest, however, is when the abandonment of legal procedure is first attempted. A nation must not perish because, in the natural frenzy of the aftermath of war, it . abandoned its central theme of the dignity of the human personality and due process of law."

The decision in Girouard v. United States, ${ }^{75}$ involving the eligibility of conscientious objectors for naturalization, touched no constitutional question. The problem was merely one of interpreting the intent of Congress. Mr. Justice Douglas for the majority pointed out that Congress had never expressly required an applicant for citizenship to pledge military service. He felt that to exact such a pledge as a condition of citizenship was so contrary to all of our national history that it should not be imposed by administrative or judicial determination, only by express Congressional action. He pointed to the fact that Congress had in 1942 permitted all members of the armed forces (including pacifist non-combatants) to become citizens and indicated that if a non-combatant pacifist could take the oath, although opposed to war, then any similarly situated pacifist should likewise be entitled to do so, even though he had not actually served in the armed forces as a non-combatant.

In his dissent, the late Chief Justice, who had originally dissented with Hughes, Holmes and Brandeis in the Macintosh case, now took the opposite view. He was motivated largely by the fact that Congress had reenacted the laws dealing with citizenship after the earlier cases had been decided without indicating any disagreement with them. And this he felt constituted a legislative approval of the earlier interpretation, which it was improper for the Court now to disregard.

It is to be hoped that this last decision finally sets this vexed question at rest and that Congress will not seek to reinstate the illiberal doctrine of the earlier cases. It is interesting to note that this is the first case in which the most recent justice, Burton, joined the liberal group.

Finally, the Selective Service cases call for brief comment. First are those which deal with the proper procedure by which a registrant might question illegal or arbitrary action by his draft board. Congress had absolutely exempted ministers from the draft and had given qualified exemption to conscientious objectors. Claims by members of Jehovah's Witnesses and others to exemption on one or another ground, were frequently rejected. Many registrants, refusing to submit to

75. 66 Sup. Ct. 826 (U. S. 1946). 
induction, were then indicted. When, in the criminal courts, they attempted to challenge the draft boards' actions, they were met with the contention that the only way in which such actions could be reviewed was in habeas corpus proceedings after induction.

When this problem first came before the Supreme Court, decision was avoided on the ground that the draft board's misconstruction of the law had been eliminated as the basis of the induction order by a finding of General Hershey to the effect that the registrant in the case was not sincere in his opposition to war. ${ }^{76}$ Soon afterwards the Court ruled that the administrative error could not be challenged until after compliance with the order ${ }^{77}$ This was widely interpreted as requiring actual submission to induction. But the Billings v. Truesdell decision ${ }^{\text {p }}$ suggested a solution. There the Court ruled that a registrant could avoid being inducted into the army by complying with the draft board order in every respect, yet at the point of induction refusing to take an oath. When, therefore, this precise method had been. followed, the Supreme Court, after the war was over, decided ${ }^{79}$ that arbitrary or illegal action by a draft board might be challenged at a criminal trial for refusal to take the oath. Unfortunately, this clarification of procedure came too late to help most of the registrants who had been unwilling to take the oath upon induction.

The Supreme Court has reviewed two other draft convictions. In one case it reversed a conviction because the evidence showed that the registrant had kept the board sufficiently advised of his address..$^{80}$ In the other it affirmed, by a vote of five to four, on the ground that the statute was not restricted to conspiracies to interfere with the draft by force or violence. ${ }^{81}$ But so far the Supreme Court has refused to review any case dealing with the merits of draft board classification, although it has been several times asked to do so. $^{82}$

76. Bowles v. United States, 319 U. S. 33 (1943) (opinion per curiam; dissenting opinion by Mr. Justice Jackson in which Mr. Justice Reed joined).

77. Falbo v. United States, 320 U. S. 549 (1944) (opinion by Mr. Justice Black, concurring opinion by Mr. Justice Rutledge; dissenting opinion by Mr. Justice Murphy).

78. Billings v. Truesdell, Maj. Gen., U.S. A., 321 U. S. 542 (1944) (opinion by Mr. Justice Douglas, concurring opinion by Mr. Justice Frankfurter; dissenting opinion by Mr. Justice Roberts).

79. Estep v. United States, 66 Sup. Ct. 423 (U. S. 1946) (opinion by Mr. Justice Douglas, concurring opinion by Messrs. Justices Murphy and Frankfurter. The latter dissented from the basis of the majority but approved reversal on different grounds having no general application; dissenting opinion by Mr. Justice Burton, joined by the Chief Justice, who agreed with Mr. Justice Frankfurter to the extent that he differed from the majority).

80. Bartchy v. United States, 319 U. S. 484 (1943) (opinion by Mr. Justice Reed; dissenting opinion by Mr. Justice Stone, in which Mr. Justice Roberts joined).

81. Singer v. United States, 323 U. S. 338 (1945) (opinion by Mr. Justice Douglas; dissenting opinion by Mr. Justice Frankfurter, joined by Messrs. Justices Roberts, Murphy and Rutledge).

82. See, e.g., United States ex rel. Lynn v. Downer, 140 F. (2d) 397 (C. C. A. 2d, 1944), 


\section{III}

What conclusions can we draw from these varying decisions? Clearly the majority of the Court is reluctant to enunciate constitutional principles of broad application and tries, whenever possible, to decide cases on narrow grounds. Also, the majority is generally reluctant to upset executive action when it has been authorized by Congress. The Japanese-American evacuation orders were thus upheld because approved by Congress, but the continued detention of Japanese-Americans and the military trials of Hawaiian civilians were condemned because Congress had not authorized such acts. ${ }^{83}$ It is noteworthy also that during this war period no congressional enactment dealing with personal liberties has been considered unconstitutional even by a dissenting justice. ${ }^{83}$

The war has brought about the final dissolution of the Black, Douglas and Murphy trio, who for so many years had been liberal dissenters. Only Justice Murphy has remained a consistent upholder of liberty, joined frequently by Justice Rutledge. Surprisingly, Justice Black has often been on the other side. And most unexpected of all was the position of the late Chief Justice ${ }^{85}$ who at one time had often joined with Holmes and Brandeis in famous dissents. It is a far cry from his position in the first flag salute case ${ }^{80}$ to his dissent in Bridges $v$. Wiron, ${ }^{\text {gT }}$ where important constitutional problems were brushed aside as being unworthy of serious consideration. The Chief Justice failed to dissent in any of the cases in which the majority decided against liberty and dissented in all but three of those cases in which the position of the government was overruled.

And the practical results? Denaturalization because of opinion was stopped and prosecution for mere anti-war statements discouraged. The right of loyal citizens of Japanese ancestry to leave detention camps was proclaimed, but at a time when most of those affected had

cert. denied 322 U. S. 756 (1914) on ground that the case had become moot. This case involved the question of segregation of races. See also United States $c x$ rel. Trainin v. Cain, 144 F. (2d) 944 (C. C. A. 2d, 1914), cert. denied 323 U.S. 795 (1945), which involved denial -of a rabbi's claim to exemption; and Swatzka v. Sullivan, 148 F. (2d) 965 (C. C. A. 9th, 1945), cest. denied 66 Sup. Ct. 90 (U. S. 1945). This case involved deferment of an agricultural worker. Denial of certiorari in the latter case is particularly regrettable breause the District Court had upheld the registrant's contention.

83. Mr. Justice Roberts intimated, however, that since Congress had ratificd detention of Japanese-Americans by appropriating money for that purpose, its action was as unconstitutional as the detention itself. Ex parte Endo, 323 U.S. 283, 310.

81. See Fraenkel, Civil Liberlies Decisions of the Supreme Couth, 1941 Term (1912) 91 U. OF PA. L. REV. 1, 27.

85. Indeed, it was Mr. Justice Stone, who first indicated that in civil liberties eares the presumption of constitutionality was less potent than in other cases, United States v.Carolene Products Co., 304 U.S. 144 (1938) at 152, n. 4.

S6. Minersville School District v. Gobitis, 310 U.S. 586, 601 (1940).

87. 326 U.S. 135,178 (1945), 
already been released. A method was found to permit draftees to challenge arbitrary draft board action without actually becoming part of the armed forces first, but opportunities to clarify the law in time to be of real help were passed by. The Supreme Court also ruled that the treason clause of the Constitution meant what it said and that, in extending the Constitution to Hawaii, Congress had not intended to limit its application and permit military trials of civilians.

On the other hand, the area of liberty has been narrowed by the rulings which allowed a state to ban a man from practicing law because he was a pacifist, which sanctioned the death sentences imposed on Japanese generals despite the strong belief of dissenting judges that they had not had fair trials and which permitted the mass evacuation from the West Coast of all persons of Japanese ancestry, aliens and citizens alike. War remains a restricter of liberty. 